DigitALCOMMONS @WAYNESTATE -

\section{Michigan Journal of Counseling: Research, Theory and Practice}

Volume 34 | Issue 1

Article 1

$5-1-2007$

\title{
From the Editorial Desk
}

Erin Radtka

Belleville High School

Follow this and additional works at: https://digitalcommons.wayne.edu/mijoc

\section{Recommended Citation}

Radtka, E. (2007). From the Editorial Desk, Dimensions of Counseling, 34(1), i. doi:10.22237/mijoc/1177977600

This From the Editor is brought to you for free and open access by the Open Access Journals at DigitalCommons@WayneState. It has been accepted for inclusion in Michigan Journal of Counseling: Research, Theory and Practice by an authorized editor of DigitalCommons@WayneState. 


\section{From the Ediforial Desk}

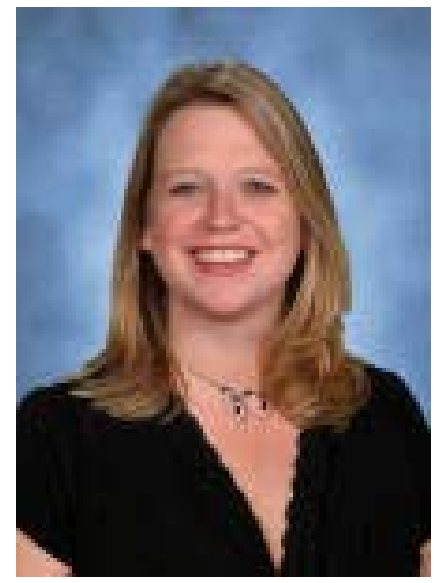

Erin Radtka, M.A., LLPC Editor

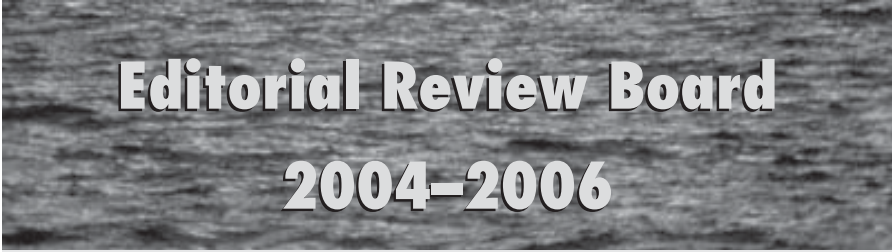

Yvonne L. Callaway, Ph.D.

Professor

Eastern Michigan University

Arnold J. Coven

Associate Professor

Wayne State University

Robert S. Fink, Ph.D.

Associate Professor

Oakland University

\section{John Geisler, Ph.D.}

Professor

Western Michigan University

Peggy Treece Myles, Ph.D.

Professor

Siena Heights University

\section{Smita Nagpal, Ph.D \\ Director}

Hudson Family Therapy

Jina Yoon

Assistant Professor

Wayne State University
Although I have enjoyed my tenure, this is my last issue as editor. The publication is in definite need of submissions, which can be sent to Dr. Arnold Coven, our new journal editor. Please see the following page for instructions for submitting manuscripts and new contact information.

This issue of the journal has an educational theme. It begins with articles of major interest to secondary school counselors, and finishes with an idea for counselor educators.

The lead article, by Dr. Elizabeth Broughton and Dr. Ronald Willamson, examines school counselors' perceptions of their role in schools. The results are surprising and the article provides solid groundwork for future research in the area.

The second article addresses a significant aspect of school counseling, underage sex. According to author Sharie Reznich, many school counselors are unaware of the Michigan Requirement to teach students about the penalties of underage sex. The article is informational, and definitely shows a need for counselor education in this area, as well as a need for school counselors to be aware of district policies regarding everything from mandates to confidentiality.

Finally, we conclude with the third article, a practice-based article by Dr. Arnold Coven, Jennifer Araujo, Katherine G. Van Hull, Shedeh Tavokoli-Moayed, Ann Collins, Jina Enwiya, and Kathleen Boyes. The article shows the effectiveness of using a group process approach for teaching consultation skills to doctoral students.

Erin Radtka, MA, LLPC, NCC, is a school counselor at Belleville High School and is the Editor of Dimensions of Counseling: Research, Theory and Practice. 